Editorial

\title{
Developing Lyell's Legacy: Contributions to the Geosciences of the Anthropocene
}

\author{
Carlos Alves \\ LandS/Lab2PT Lab2PT, Landscape, Heritage and Territory Laboratory (FCT UID/AUR/04509/2013; FEDER \\ COMPETE POCI-01-0145-FEDER-007528) and Earth Sciences Department, School of Sciences, Campus de \\ Gualtar, University of Minho, Braga 4710-057, Portugal; casaix@dct.uminho.pt
}

Academic Editor: Jesus Martinez-Frias

Received: 24 November 2016; Accepted: 28 November 2016; Published: 30 November 2016

In this new edition of the Geoscience of the Built Environment [1], we hope to continue our contribution to the development of Geosciences studies in the Anthropocene, considering classical issues that are at least as old as Charles Lyell's major works [2,3], which can be considered the founding literary works of modern Geology. The Anthropocene is currently being discussed as a possible Unit in the Geological Time Scale [4], and its definition is still a controversial issue [5]. It has also been proposed that the Anthropocene marks the end of "a time of great epistemic stability" [6] and that new approaches and ways of thinking will be necessary [6,7]; a question that is also implicitly considered in a forthcoming issue of this journal [8].

The Geosciences of the future (as is discussed in the proposal of [8]), done in the Anthropocene, will have to go beyond the geological record and embrace studies on the relations between humans and Earth, including the evolution of built objects due to geological processes. I will attempt to discuss some of the kinds of issues to be considered using the papers of this Special Issue and in the light of the major works of Lyell (attempting to show the links of these issues to the founding concepts of Geology).

In the Principles of Geology [2], Charles Lyell presented Geology as "the science which investigates the successive changes that have taken place in the organic and inorganic kingdoms of nature; it inquiries into the causes of these changes, and the influence which they have exerted in modifying the surface and external structure of our planet". In the Manual of Elementary Geology [3], Lyell justifies the concern of Geology with the superficial portions of the planet (crust) given that "although the dimensions of such a crust are, in truth, insignificant when compared to the entire globe, yet they are vast, and of magnificent extent in relation to man, and to the organic beings which people our globe" (the highlight of the relevance to humans is clear).

Lyell presents in [3] several examples of how to relate terrain features to geological structures. Lyell also considered, in [2], diverse examples of the effects of geologic phenomena on human structures (such as earthquakes, volcanic eruptions and geomorphological processes) but also examples of how human action can affect geological processes. In a case that illustrates how human actions could influence natural processes which might affect human structures and activities, Lyell refers [2] to a certain rock terrain that was "quarried for lime to such an extent that the sea broke through, and in 1795 carried away the whole village in one night, and penetrated 150 yards inland, where it has maintained its ground ever since, the new village having been built farther inland on the new shore". The paper by Theilen-Willige and collaborators [9] uses several modern techniques to "read" features from the terrain in relation to the possible impact of human structures on seismicity (which might have impacts on other human structures). The paper by Perez-Monserrat and collaborators [10] can be considered a variant of this perspective, studying processes that affect geologic materials in human structures and that include the effects of other human activities. 
The work of Lyell [2] also considered the presence of marks of human activity in the geological record. Lyell described what can be considered the integration of human artefacts in Anthropocene formations and compares this with the integration of other organisms' marks in petrological processes [2]: "Millions of silver dollars and other coins have been sometimes submerged in a single ship, and on these, when they happen to be enveloped in a matrix capable of protecting them from chemical changes, much information of historical interest will remain inscribed, and endure for periods as indefinite as have the delicate markings of zoophytes or lapidified plants in some of the ancient secondary rocks". There are other examples in [2], where human objects are seen as part of petrological (sedimentary) processes, writing that when "a vessel is stranded in shallow water, it usually becomes the nucleus of a sand-bank" and referring to a case of "a very curious old swivel gun" where the "swivel and pivot on which it turned were of iron. Around these latter were formed incrustations of sand converted into a kind of stone, of exceedingly strong texture and firmness" (in this way, he seemed to allow more latitude in Geology than the International Mineralogical Association admits in Mineralogy, as this organization has ruled that products arising from interactions between human products and natural processes, even when that interaction is unintended, should not be considered mineral species-see [11]). Lyell's perspective just presented extends to humans what the same author considered, in other portions of [2], to be in relation to marine organisms ("a stone said to be continually forming on the beach, where the waves threw up small rounded fragments of shells and corals, which, in the course of time, become firmly agglutinated together, and constitute a stone used largely for building and making lime") but also big animals, such as camels ("the African sand-winds, before described, raise a small hillock over the carcass of every dead camel exposed on the surface of the desert"). Further highlighting the integration of human activities in the Geosciences, one can mention Lyell's references to processes on the human-built environment that might be considered as analogies of geological processes, such as when, to explain certain textures in travertines, Lyell writes "In the same manner I have seen, on the vertical walls of large steam-boilers, the heads of nails or rivets covered by a series of enveloping crusts of calcareous matter, usually sulphate of lime; so that a concretionary nodule is formed, preserving a nearly globular shape, when increased to a mass several inches in diameter". This Special Issue also addresses [10] how geologic materials in human structures can be used as markers of pollution and climate change. These apparently distant issues are in fact strongly related and they might prompt other research issues, namely: How will climate change affect dam-related seismicity? Perhaps higher rates of rain rates change might induce higher seismicity?

Cultural aspects pervade Lyell's works and some portions frequently seem today like texts of archaeology. Praising Werner's teaching, Lyell states [3] that "The qualities of certain stones used in building would lead him to descant on the architecture of different ages and nations". My own research work can be considered to be mostly related to geologic materials in the built environment and it has been developed in Braga (NW Portugal), a region where several examples of granite uses in the historical heritage can be found. In the accompanying text of the 1:50,000 geological map of Braga [12], there are expressions that relate cultural objects to Geology, such as the reference to a certain stone objects that showed "the skilful and artful way of working the granite that the ancient inhabitants knew" (my translation) and the reference to a fine-grained leucocratic granite that "by its fine grain and light colour gives such an excellent look" (my translation) to the buildings where it was used. The paper by Pereira and Marker [13] highlights the several issues that make natural stone such a valuable material, both in terms of historical perspectives and in terms of future interventions.

Other papers in this Special Issue [14-17] reflect the architectural and cultural value of other geologic materials (including materials derived from geologic materials).

Geological studies have played the main role in the apprehension of time (earlier than the astronomical studies on the "Big Bang"). The question of time (and dating of events) has a preeminent role in Lyell's work and in [2] human artefacts are considered as potential elements for dating geologic formations (and their absence in older formations is considered an indication of the recent origin of humans). The papers of Sanjurjo-Sánchez [14] and of Straulino-Mainou and collaborators [15] continue 
this tradition, in these cases using geologic materials or materials derived from geologic sources as tools for dating built structures.

However, geological materials are also a part of the future, as is shown in the papers by Stefanidou [16] and by Rempel and Rempel [17] and their characteristics can be considered in terms of their applications to the recovery of older buildings but also for new works. Besides their technical performance, geological materials can have important environmental impacts, including the improvement of habitation conditions.

In a recent biography of Alexander von Humboldt (whose work precedes Lyell's), Andrea Wulf [18] refers to how Humboldt noted the impact of human activities on soil erosion and climate (one can consider that he was one of the precursors of the idea of the Anthropocene). According to Wulf [18], the perspective presented by Humboldt and for some of his intellectual descendants (such as George Marsh and John Muir) is of humans as disturbers of the natural equilibrium (but Wulf comments that George Marsh approached the subject from the point of view of resources management and preservation for better use). There are other examples of impacts of organisms on a global scale. Biological contributions are frequently considered for the Great Oxidation Event (but see a recent discussion in [19]). Assessing the impact of humans "in the vegetable kingdom", Lyell wrote [2] that "it may not so much consist in the kind or absolute quantity of alteration, as in the circumstance that a single species, in this case, would exert, by its superior power and universal distribution, an influence equal to that of hundreds of other terrestrial animals". The review by Thomson and Newman [20] assumes the role of humans as geological agents on the Anthropocene and highlights how the management of activities on the built environment, including "regenerative urbanism" (which concerns activities that can have net positive impacts on the environment) can influence that role and allow built environment activities to be a major "geoengineering force".

We hope, hence, that the papers of this Special Issue contribute to the integration of humans in the Geosciences studies of the Anthropocene.

Conflicts of Interest: The author declares no conflict of interest.

\section{References}

1. Geosciences Web Page. Special Issue “Geoscience of the Built Environment 2016 Edition”. Available online: http://www.mdpi.com/journal/geosciences/special_issues/geoscience-built-environment2016 (accessed on 21 November 2016).

2. Lyell, C. Principles of Geology or, the Modern Changes of the Earth and Its Inhabitants Considered as Illustrative of Geology, 9th ed.; D. Appleton \& Company: New York, NY, USA, 1854.

3. Lyell, C. A Manual of Elementary Geology or, the Ancient Changes of the Earth and Its Inhabitants as Illustrated by Geological Monuments, 4th ed.; John Murray: London, UK, 1852.

4. Working Group on the "Anthropocene" What Is the "Anthropocene"?-Current Definition and Status. Available online: http:/ / quaternary.stratigraphy.org/workinggroups/anthropocene/ (accessed on 21 November 2016).

5. Hamilton, C. Define the Anthropocene in terms of the whole earth. Nature 2016, 536, 251. [CrossRef] [PubMed]

6. Maggs, D.; Robinson, J. International association for environmental philosophy recalibrating the Anthropocene: Sustainability in an imaginary world. Environ. Philos. 2016, 13, 175-194. [CrossRef]

7. Nicholson, S.J.; Jinnah, S. New Earth Politics: Essays from the Anthropocene; The MIT Press: Cambridge, MA, USA, 2016.

8. Geosciences Web Page. Special Issue “Geosciences and Future Earth”. Available online: http://www.mdpi. com/journal/geosciences/special_issues/GeosciencesFutureEarth/ (accessed on 21 November 2016).

9. Theilen-Willige, B.; Aher, S.; Gawali, P.; Venkata, L. Seismic hazard analysis along Koyna Dam area, western Maharashtra, India: A contribution of remote sensing and GIS. Geosciences 2016, 6, 20. [CrossRef]

10. Perez-Monserrat, E.; Varas-Muriel, M.; De Buergo, A.M.; Fort, R. Black layers of decay and color patterns on heritage limestone as markers of environmental change. Geosciences 2016, 6, 4. [CrossRef] 
11. Nickel, E.H. The definition of a mineral. Can. Mineral. 1995, 33, 689. [CrossRef]

12. Teixeira, C.; Medeiros, A.C.; Macedo, J.R. Carta geológica de Portugal na Escala 1/50 000: Notícia Explicativa da folha 5-D (Braga); Serviços Geológicos de Portugal: Lisbon, Portugal, 1973. (In Portuguese)

13. Pereira, D.; Marker, B. The value of original natural stone in the context of architectural heritage. Geosciences 2016, 6, 13. [CrossRef]

14. Sanjurjo-Sánchez, J. An overview of the use of absolute dating techniques in ancient construction materials. Geosciences 2016, 6, 22. [CrossRef]

15. Straulino Mainou, L.; Sedov, S.; Soler Arechalde, A.; Pi Puig, T.; Villa, G.; Balanzario Granados, S.; Doménech-Carbó, M.-T.; Osete-Cortina, L.; Leonard, D. Maya lime mortars-Relationship between archaeomagnetic dating, manufacturing technique, and architectural function-The Dzibanché case. Geosciences 2016, 6, 49. [CrossRef]

16. Stefanidou, M. Crushed and river-origin sands used as aggregates in repair mortars. Geosciences 2016, 6, 23. [CrossRef]

17. Rempel, A.R.; Rempel, A.W. Intrinsic evaporative cooling by hygroscopic earth materials. Geosciences 2016, 6, 38. [CrossRef]

18. Wulf, A. The Invention of Nature: The Adventures of Alexander von Humboldt, the Lost Hero of Science; John Murray: London, UK, 2015.

19. Ciborowski, T.J.R.; Kerr, A.C. Did mantle plume magmatism help trigger the Great Oxidation Event? Lithos 2016, 246, 128-133. [CrossRef]

20. Thomson, G.; Newman, P. Geoengineering in the Anthropocene through Regenerative Urbanism. Geosciences 2016, 6, 46. [CrossRef]

(C) 2016 by the author; licensee MDPI, Basel, Switzerland. This article is an open access article distributed under the terms and conditions of the Creative Commons Attribution (CC-BY) license (http://creativecommons.org/licenses/by/4.0/). 